\title{
Field studies of leaf gas exchanges in oil palm tree (Elaeis guineensis Jacq.)
}

\author{
E. Dufrene and B. Saugier
}

Laboratoire d'Ecologie Végétale, Université Paris-Sud, 91405 Orsay Cedex, France

\section{Introduction}

This study is part of a larger research program on climatic and biological factors affecting oil palm yield. Our purpose was to characterize, under conditions of good water supply, variations in leaf photosynthesis with internal and external factors.

Several authors have been working on the $\mathrm{CO}_{2}$ assimilation rate $(A)$ in oil palm. Most of them have used young plants under laboratory conditions to study effects of photosynthetically active radiation (Corley et al., 1973; Hirsch, 1975), foliar temperature (Hong and Corley, 1976) or leaf water potential and stomatal conductance (Adjahossou, 1983). Only 2 experiments were conducted in the field: Bolle-Jones (1968) determined the amount of soluble sugars in 9 yr old leaflets and Corley (1983) observed the effects of leaf senescence on photosynthesis using the ${ }^{14} \mathrm{CO}_{2}$ method.
In this study, we evaluated variations in leaf photosynthesis in 8 trees of the same progeny, and the effect of vapor pressure deficit $\left(V P D=e_{\mathrm{s}}\left(T_{\mathrm{a}}\right)-e_{\mathrm{a}}\right)$ and leaf temperature $\left(T_{f}\right)$ on stomatal conductance and leaf gas exchanges.

\section{Materials and Methods}

The study site was located at the I.R.H.O.1/C.I.R.A.D. ${ }^{2}$ experimental station of $\mathrm{La}$ Mé near Abidjan, Ivory Coast $\left(5^{\circ} 26^{\prime} \mathrm{N}\right.$ Lat., $3^{\circ} 50^{\prime} \mathrm{W}$ Long.). The studied trees belong to one single line (L2T*D10D) used as a reference in many trials of the production area and characterized by a moderate vegetative development associated with good bunch production.

The net $\mathrm{CO}_{2}$ assimilation rate $(A)$ was measured using a leaf chamber (PLC, A.D.C. ${ }^{3}$ ) and a portable $\mathrm{CO}_{2}$ analyzer (LCA2, A.D.C.) connected in an open system. Leaf temperature, transpiration rate, boundary layer and stomatal conductances were calculated using the energy balance equation (Parkinson, 1985) combined with standard equations (von Caemmerer and Farquhar, 1981).

\footnotetext{
1 I.R.H.O.: Institut de Recherche sur les Huiles et les Oléagineux.

2 C.I.R.A.D.: Centre de Cooperation International en Recherche Agronomique pour le Développement.

3 A.D.C.: Analytical Development Company.
} 


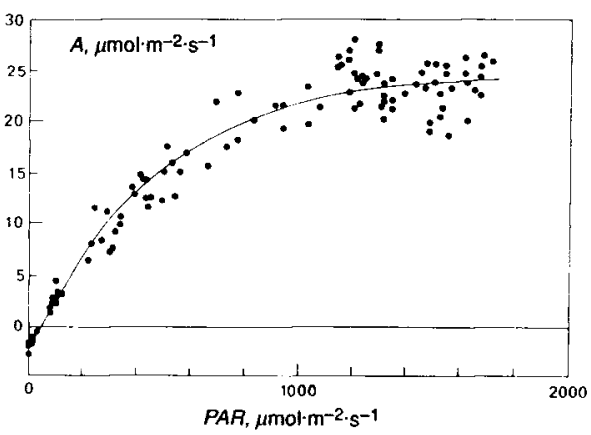

Fig. 1. Rate of $\mathrm{CO}_{2}$ uptake (A), versus incident photosynthetically active radiation (PAR), in young leaves $(8$ trees). $V P D$ lower than $0.4 \mathrm{kPa}, T_{\mathrm{f}}$ varies from 29 to $37^{\circ} \mathrm{C}$ and $g_{s}$ higher than $9 \mathrm{~mm} \cdot \mathrm{s}^{-1}$.

\section{Results}

Fig. 1 shows measurements made on the 8 th or 9th leaf of 8 different palm trees (last leaf fully opened is numbered 1). Light was the only limiting factor. Relative error of measurements in low light was too high to allow a comparison of apparent quantum yield between trees.

Maximal leaf assimilation rates (PAR higher than $\left.1100 \mu \mathrm{mol} \cdot \mathrm{m}^{-2} \cdot \mathrm{s}^{-1}\right)$ were not significantly different between trees $(F=1$, $\mathrm{d} F=52$ ).

The maximal $\mathrm{CO}_{2}$ assimilation rate decreased with leaf age in $10 \mathrm{yr}$ old oil palm (Fig. 2). This decrease became more pronounced at leaf number higher than 25 $(\approx 2 \mathrm{yr}$ old $)$, when maximal stomatal conductance was also decreasing.

The net $\mathrm{CO}_{2}$ assimilation rate was slightly sensitive to $V P D$ increase up to $1.7 \mathrm{kPa}$, and then it dropped steadily (Fig. 3a). The transpiration rate decreased linearly with VPD because of rapid stomatal closing (Fig. 3a, b). There was no change in the $\mathrm{CO}_{2}$ assimilation rate as a result of changes in leaf temperature (Fig. $3 c)$. The transpiration rate and stomatal

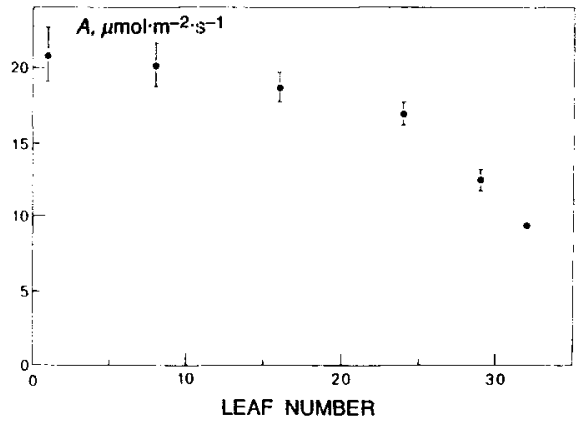

Fig. 2. Response to changes in leat age of maximal assimilation rate $(A)$. PAR higher than 1100 $\mathrm{mol} \cdot \mathrm{m}^{-2} \cdot \mathrm{s}^{-1}$.

conductance increased with leaf temperature (Fig. 3c, cl).

\section{Discussion and Conclusion}

The maximal photosynthesis observed in $5 \mathrm{yr}$ old oil palm $\left(A=23.70 \mu \mathrm{mol} \cdot \mathrm{m}^{-2} \cdot \mathrm{s}^{-1}\right)$ was not very different from Corley's (1983) results $\left(A=20 \mu \mathrm{mol} \cdot \mathrm{m}^{-2} \cdot \mathrm{s}^{-1}, 3 \mathrm{yr}\right.$ old trees, leaf number 10). This high $\mathrm{CO}_{2}$ assimilation rate is quite similar to those of fast growing temperate trees, such as Populus sp. (Ceulemans et al., 1987) and slightly higher than those of wet tropical forest and crop trees (Mooney et al., 1984. Leaf temperature between 30 and $38^{\circ} \mathrm{C}$ had no effect on photosynthesis which shows an adaptation to high temperatures in this tropical $\mathrm{C}_{3}$ species.

Observed stomatal opening with increases in temperature is a classical response that is often concealed by a simultaneous variation in VPD (Jarvis and Morison, 1981). When VPD increases above about $1 \mathrm{kPa}$, it causes a rapid stomatal closure that induces a decrease in the transpiration rate, despite a high eva- 

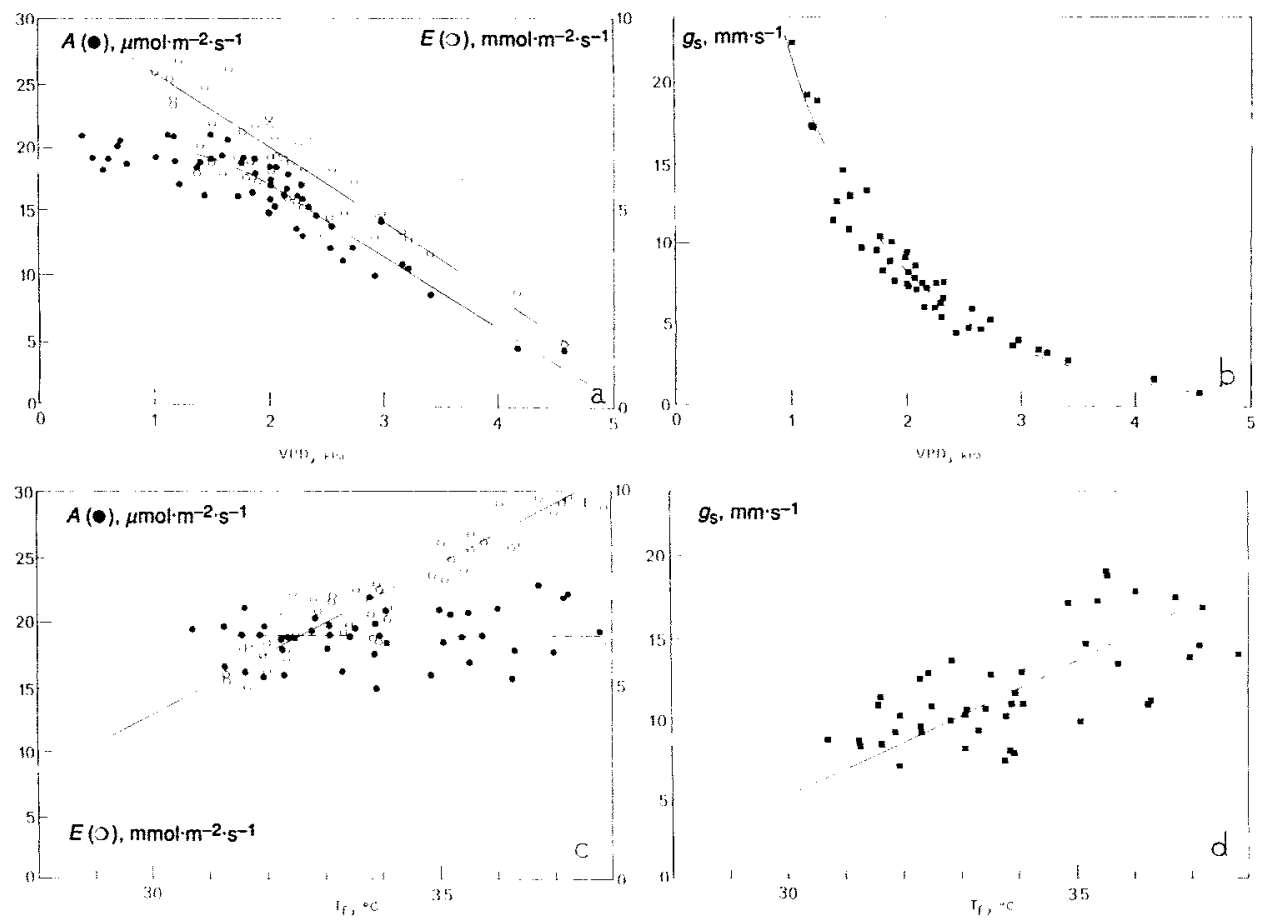

Fig. 3. Rate of transpiration $(E)$, rate of $\mathrm{CO}_{2}$ uptake $(A)$, and stomatal conductance $\left(g_{\mathrm{s}}\right)$, versus vapor pressure deficit ( $a$ and $b$ ) and, leaf temperature (c and d) with $V P D$ varying from 1 to $1.8 \mathrm{kPa}$.

porative demand. Stomatal sensitivity to $V P D$ has been reported in numerous species (Farquhar et al., 1980; El Sharkawy et al., 1984). It is especially pronounced in oil palm and confers good survival capability to overcome drought to this species but strongly reduces bunch production.

\section{References}

Adjahossou D.F. (1983) Contribution à l'étude de la résistance à la sécheresse chez le palmier à huile (Elaeis guineensis Jacq.) Ph.D. Thesis, Université Paris VII, France

Bolle-Jones E.W. (1968) Variations of chlorophyll and soluble sugar in oil palm leaves in relation to position, time of day and yield. Oleagineux $23,505-511$
Ceulemans R., Impens I. \& Steenackers V. (1987) Variations in photosynthetic, anatomical and enzymatic leaf traits and correlations with growth in recently selected Populus hybrids. Can. J. For. Res. 17, 273-283

Corley R.H.V. (1983) Photosynthesis and age of oil palm leaves. Photosynthetica 17, 97-100

Corley R.H.V., Hardon J.J. \& Ooi S.C. (1973) Some evidence for genetically controlled variation in photosynthetic rate of oil palm seedlings. Euphytica 22, 48-55

El-Sharkawy M.A., Cock J.H. \& Held A.A.K. (1984) Water use efficiency of cassava. II. Differing sensitivity of stomata to air humidity in cassava and other warm-climate species. Crop Sci. 24, 505-507

Farquhar G.D., Schulze E.D. \& Kuppers M. (1980) Responses to humidity by stomata Nicotiana glauca $\mathrm{L}$. and Corylus avellana $\mathrm{L}$. are consistent with the optimization of carbon dioxide uptake with respect to water loss. Aust. $J$. Plant Physiol. 7, 315-327 
Hirsch P.J. (1975) Premiers travaux sur l'assimilation photosynthétique du palmier a huile (Elaeis guineensis Jacq.). Thesis, ORSTOMRHO, La Mé, Ivory Coast

Hong T.K. \& Corley R.H.V. (1976) Leaf temperature and photosynthesis of a tropical $\mathrm{C}_{3}$ plant Elaesis guineensis. Mardi Res. Bull. 4, 1620

Jarvis P.G. \& Morison J.I.L. (1981) Stomatal control of transpiration and photosynthesis. In: Stomatal Physiology. (Jarvis P.G. \& Mansfield T.A., eds.), Cambridge Univ. Press, Cambridge, pp. 247-279
Mooney H.A., Field C. \& Vasquez-Yanes C. (1984) Photosynthetic characteristics of wet tropical forest plants. In: Physiological Ecology of Plants of the Wet Tropics. (Medina E., et al., eds.), Dr. W. Junk Publ., The Hague, pp. 113128

Parkinson K.J. (1985) A simple method for determining boundary layer resistance in leaf cuvettes. Plant Cell Environ. 8, 223-226

von Caemmerer S. \& Farquhar G.D. (1981) Some relationships between the biochemistry of photosynthesis and the gas exchange of leaves. Planta 153, 376-387 